\title{
PENINGKATAN KEMAMPUAN GURU DALAM MERANCANG INSTRUMEN PENILAIAN HASIL BELAJAR MELALUI KEGIATAN IN HOUSE TRAINING (IHT) DI SEKOLAH DASAR
}

\author{
Samsul Bahri \\ Kepala SD Negeri Alue Gureb, Kec. Peureulak Timur, Kab. Aceh Timur \\ samsulbahrialuegureb@gmail.com
}

\begin{abstract}
The research aims to improve the ability of teachers in developing learning outcomes assessment instruments through the implementation of In House Training (IHT) activities at Alue Gureb Elementary School in 2018-2019 academic year. This study also describes the teacher's understanding of the substance of the learning outcomes assessment instrument. This research is classified as a school action research involving 10 teachers as research subjects. The study was conducted in two cycles and each cycle consisted of 4 stages: planning, implementing, observing and reflecting. The determined performance indicators are: if a minimum of $85 \%$ of teachers is classified as capable and good towards the preparation of learning outcomes assessment instruments, then it can be said that the actions implemented are successful. The aspect measured in assessing the success of the action is the readiness of the teacher to take part in the In House Training (IHT) activity and the results of the implementation of the In House Training (IHT) activity.
\end{abstract}

Keywords: In House Training (IHT) Activities, Teacher's Ability in Developing Learning Outcomes Assessment Instruments

ABSTRAK
Penelitian ini dilaksanakan bertujuan untuk meningkatkan kemampuan guru dalam menyusun
instrumen penilaian hasil belajar melalui implementasi kegiatan In House Training (IHT) di SD
Negeri Alue Gureb tahun pelajaran 2018-2019. Selain itu, penelitian ini juga bertujuan untuk
mendeskripsikan pemahaman guru terhadap substansi instrumen penilaian hasil belajar. Penelitian ini
tergolong penelitian tindakan sekolah dengan melibatkan 10 orang guru sebagai subjek penelitian.
Penelitian dilakukan dengan dua siklus dan masing-masing siklus terdiri atas 4 tahapan, yakni:
perencanaan, pelaksanaan, observasi dan refleksi. Indikator kinerja yang ditetapkan adalah: bila
minimal $85 \%$ guru tergolong mampu dan baik terhadap penyusunan instrumen penilaian hasil belajar,
maka sudah dapat dikatakan tindakan yang diterapkan berhasil. Aspek yang diukur dalam menilai
keberhasilan tindakan adalah kesiapan guru mengikuti kegiatan In House Training (IHT) dan hasil
pelaksanaan kegiatan In House Training (IHT)

Kata Kunci: Kegiatan In House Training (IHT), Kemampuan Guru dalam Menyusun Instrumen Penilaian Hasil Belajar

Author correspondence

Email: samsulbahrialuegureb@gmail.com

Available online at http://ejurnalunsam.id/index.php/jsnbl/index 
SEUNEUBOK LADA

Jurnal Ilmu-Ilmu Sejarah, Sosial, Budaya dan Kependidikan, 7 (1), 2020: 93-106

ISSN : 2356-0770

e-ISSN : 2685-2705

\section{A. PENDAHULUAN}

Kebijakan peningkatan mutu pendidikan dan pengajaran harus selalu diupayakan oleh berbagai pihak, baik pemerintah maupun komponen lain yang terlibat dalam proses tersebut. Guru sebagai salah satu komponen di dalamnya memiliki tugas dan tanggung jawab yang besar. Karena masa depan suatu bangsa ditentukan oleh guru yang berkualitas. Tugas dan tanggung jawab tersebut tidak hanya sekedar membuat peserta didik menjadi tahu dan memahami bahan ajar yang diberikan, tetapi dapat menjadikan peserta didik menjadi manusia terdidik yang memahami perannya sebagai manusia, sehingga bermanfaat bagi diri dan lingkungan sekitarnya.

Hal ini dapat dimengerti, karena guru yang bermutu adalah mereka yang mampu membelajarkan peserta didik secara efektif, sesuai dengan kendala, sumber daya, dan lingkungannya. Dilain pihak, mutu guru sangat berkaitan erat dengan pengakuan masyarakat atas status guru sebagai suatu jabatan profesional. Karenanya, guru dituntut untuk meningkatkan kualitas kompetensi mendidik dan sikap profesional yang tinggi (Pidarta: 2000: 34). Tugas dan tanggung jawab tersebut tidak hanya sekedar membuat peserta didik menjadi tahu dan memahami bahan ajar yang diberikan, tetapi dapat menjadikan peserta didik menjadi manusia terdidik yang memahami perannya sebagai manusia, sehingga bermanfaat bagi diri dan lingkungan sekitarnya.

Guru sebagai fasilitator yang mengelola proses pembelajaran di kelas mempunyai andil dalam menentukan kualitas pendidikan. Konsekuensinya adalah guru harus mempersiapkan segala sesuatu agar proses pembelajaran di kelas berjalan dengan efektif. Perencanaan pembelajaran merupakan langkah yang sangat penting sebelum pelaksanaan pembelajaran. Perencanaan yang matang diperlukan supaya pelaksanaan pembelajaran berjalan secara efektif. Perencanaan pembelajaran dituangkan ke dalam Rencana Pelaksanaan Pembelajaran (RPP) atau beberapa istilah lain seperti desain pembelajaran, skenario pembelajaran. RPP memuat SK, KD, indikator yang akan dicapai, materi yang akan dipelajari, metode pembelajaran, langkah pembelajaran, media pembelajaran, dan sumber belajar serta penilaian.

Demikian halnya keadaan di SD Negeri Alue Gureb, Kecamatan Peureulak Timur, Kabupaten Aceh Timur. Sebagian besar guru mengalami kesulitan dalam merancang instrumen penilaian hasil belajar. Disebabkan tidak adanya pelatihanpelatihan yang pernah diikuti peserta, tentang pengembangan penyusunan instrumen penilaian dalam pembelajaran yang diadakan di sekolah. Kondisi tersebut berdampak pada sering tidak sesuainya perencanaan dengan pelaksanaan yang dilakukan di kelas. Keadaan yang kurang menggembirakan tersebut didukung oleh hasil penilaian pada tiga aspek kinerja guru yang meliputi perencanaan pembelajaran, pelaksanaan pembelajaran, dan penilaian pembelajaran. 
Berdasarkan hasil supervisi terhadap guru masih dominan menggunakan pengelolan pembelajaran berdasarkan pola lama dan masih dominan menggunakan rancangan instrumen penilaian hasil belajar yang tidak sesuai karakteristik siswa dan situasi kelas. Bila ditelusuri lebih lanjut, faktor yang menyebabkan guru belum mampu melaksanakan merancang instrumen penilaian hasil belajar karena kemampuan belum optimal, bahkan ada yang tidak membuat. Hasil supervisi menunjukkan bahwa dari 10 orang guru hanya 2 orang (20\%) guru yang mampu merancang instrumen penilaian hasil belajar dan sudah menerapkannya. Sedangkan selebihnya sebanyak 8 orang guru $(80 \%)$ belum mampu merancang instrumen penilaian hasil belajar serta belum bisa menerapkan dalam proses pembelajaran. Selebihnya masih meng-copy paste rancangan instrumen penilaian hasil belajar sekolah lain dengan beberapa perubahan-perubahan.

Permasalahan tersebut tentu saja tidak dapat dibiarkan terus menerus, tetapi harus ada solusi atau tindakan nyata dari kalangan para kepala sekolah dan pengawas. Berkaitan dengan itu, para guru harus dibina dan diberikan pelatihan untuk meningkatkan kemampuannya dalam menyusun rancangan instrumen penilaian hasil belajar. Kondisi tersebut perlu menjadi perhatian bagi Kepala Sekolah untuk melakukan tindakan perbaikan. Pada pelaksanaan Kurikulum 2013 menuntut kemampuan guru untuk dapat mengelola proses pembelajaran secara efektif dan efisien. Tingkat produktivitas sekolah dalam memberikan pelayanan secara efisien kepada peserta didik akan sangat tergantung pada kualitas gurunya yang terlibat langsung dalam proses pembelajaran dan keefektifan mereka dalam melaksanakan tanggung jawab individual dan kelompok. Berdasarkan kenyataan begitu berat dan kompleksnya tugas serta peran guru tersebut, perlu diadakan pembinaan terhadap guru secara terus menerus untuk meningkatkan kinerjanya. Kinerja guru perlu ditingkatkan agar usaha membimbing siswa untuk belajar dapat berkembang. Proses pengembangan kinerja guru terbentuk dan terjadi dalam kegiatan belajar mengajar. Tindakan perbaikan yang dapat dilakukan Kepala Sekolah adalah melalui kegiatan In House Training (IHT).

Kegiatan In House Training merupakan program pelatihan yang diselenggarakan di tempat sendiri, sebagai upaya untuk meningkatkan kompetensi guru, dalam menjalankan pekerjaannya dengan mengoptimalkan potensi-potensi yang ada (Lulu, 2011). Kegiatan tersebut dapat dilaksanakan di sekolah dengan pertimbangan bahwa dapat digunakan untuk meningkatkan kemampuan dan kompetensi bersama guru lain yang memiliki kompetensi sesuai dengan tugasnya sebagai guru. Dengan strategi ini diharapkan dapat lebih menghemat waktu, biaya, dan dapat mendayagunakan potensi yang ada di sekolah.

Kegiatan In House Training (IHT) merupakan kegiatan yang sudah sering dilakukan oleh berbagai kalangan dan meliputi berbagai bidang. Kegiatan In House Training (IHT) memang sangat bermanfaat, sehingga banyak pihak yang sering 
menyelenggarakan kegiatan tersebut. Kegiatan In House Training (IHT) tidak hanya dilakukan dalam dunia pendidikan, informasi yang didapat dari In House Training (IHT) akan membantu dalam menjalani suatu kegiatan yang tentunya sesuai dengan materi yang dibahas dari In House Training (IHT) tersebut. Penyusunan instrumen penilaian hasil belajar sangat penting, karena hasil belajar peserta didik akan diketahui melalui penilaian hasil belajar sesuai indikator. Untuk mengatasi hal tersebut perlu diupayakan pembinaan dari kepala sekolah sebagai pemimpin di sekolah tersebut.

Berdasarkan latar belakang permasalahan tersebut di atas, peneliti tertarik untuk melakukan penelitian tindakan sekolah yang berkaitan dengan peran Kepala Sekolah dalam meningkatkan kemampuan guru dalam menyusun rancangan instrumen penilaian hasil belajar. Adapun judul yang diangkat dalam artikel ini adalah "Peningkatan Kemampuan Guru dalam Merancang Instrumen Penilaian Hasil Belajar Melalui Kegiatan In House Training (IHT) di Sekolah Dasar".

\section{B. TINJAUAN PUSTAKA}

\section{Hakikat Mengajar}

Mengajar merupakan suatu perbuatan yang memerlukan tanggung jawab moral yang cukup berat. Berhasilnya pendidikan pada siswa sangat bergantung pada pertanggungjawaban guru dalam melaksanakan tugasnya. Guru adalah kreator proses belajar mengajar. Ia adalah orang yang akan mengembangkan suasana bebas bagi siswa untuk mengkaji apa yang menarik minatnya, mengekspresikan ide-ide dan kreativitasnya dalam batas-batas norma-norma yang ditegakkan secara konsisten. Dengan demikian dapat dikemukakan bahwa orientasi pengajaran dalam konteks belajar mengajar diarahkan untuk pengembangan aktivitas siswa dalam belajar (Hamalik, 2008: 78)

Gambaran aktivitas itu tercermin dari adanya usaha yang dilakukan guru dalam kegiatan proses belajar mengajar yang memungkinkan siswa aktif belajar. Oleh karena itu mengajar tidak hanya sekedar menyampaikan informasi yang sudah jadi dengan menuntut jawaban verbal melainkan suatu upaya integratif ke arah pencapaian tujuan pendidikan. Dalam konteks ini guru tidak hanya sebagai penyampai informasi tetapi juga bertindak sebagai fasilitator pembelajaran.

Berdasarkan definisi-definisi mengajar dari para pakar di atas dapat ditarik kesimpulan bahwa mengajar adalah aktivitas kompleks yang dilakukan guru dalam menyampaikan pengetahuan kepada siswa, sehingga terjadi proses belajar. Aktivitas kompleks yang dimaksud antara lain adalah 1) mengatur kegiatan belajar siswa, 2) memanfaatkan lingkungan, baik ada di kelas maupun yang ada di luar kelas, dan 3) memberikan stimulus, bimbingan pengarahan, dan dorongan kepada siswa. 
SEUNEUBOK LADA

Jurnal Ilmu-Ilmu Sejarah, Sosial, Budaya dan Kependidikan, 7 (1), 2020: 93-106

ISSN : 2356-0770

e-ISSN : 2685-2705

\section{Hakikat Kemampuan Guru}

Kemampuan guru tidak lain adalah kompetensi seorang guru yang memenuhi standar yang terdiri dari empat komponen kompetensi yang terdiri dari: kompetensi pengelolaan pembelajaran, kompetensi wawasan kependidikan, kompetensi akademik/vokasional, dan kompetensi pengembangan profesi. Kemampuan diartikan sebagai pengetahuan, keterampilan dan nilai-nilai dasar yang direfleksikan dalam kebiasaan berfikir dan bertindak (Sagala, 2009: 34). Dengan demikian kemampuan atau kompetensi yang dimiliki oleh setiap guru akan menunjukkan kualitas guru yang sebenarnya.

Kemampuan guru mencerminkan tugas dan kewajiban guru yang harus dilakukan sehubungan dengan arti jabatan guru yang menuntut suatu kompetensi tertentu sebagaimana telah disebutkan (Syaeffudin, 2010: 229). Jadi kompetensi guru dapat dimaknai sebagai kebulatan pengetehuan, keterampilan dan sikap yang berwujud tindakan cerdas dan penuh tanggungjawab dalam melaksanakan tugas sebagai agen pembelajaran.

Dengan demikian dapat disimpulkan bahwa, kemampuan guru adalah salah satu faktor yang mempengaruhi tercapainya tujuan pembelajaran dan pendidikan disekolah, namun kompetensi guru tidak berdiri sendiri, tetapi dipengaruhi latar belakang pendidikan, pengalaman mengajar, dan lamanya mengajar. Kompetensi guru dapat dinilai penting sebagai alat seleksi dalam penerimaan calon guru, juga dapat dijadikan sebagai pedoman dalam rangka pembinaan dan pengembangan tenaga guru.

\section{Peran Kepala Sekolah Sebagai Pemimpin di Sekolah}

Dimasa lalu, kepala sekolah yang berperan sebagai manajer yang efektif telah dianggap cukup. Dimasa itu, kebanyakan kepala sekolah diharapkan mentaati ketentuan dan kebijakan Dinas Pendidikan, mengatasi isu-isu ketenagaan, pengadaan fasilitas dan infrastruktur, menyesuaikan anggaran, memelihara agar gedung sekolah nyaman dan aman, memelihara hubungan dengan masyarakat, memastikan kantin sekolah dan UKS berjalan lancar. Semua ini masih tetap harus dilakukan oleh kepala sekolah. Akan tetapi, sekarang kepala sekolah harus melakukan hal yang lebih dari semua itu.

Hadi (2009: 2) menyatakan bahwa dari sisi leadership menunjukkan peran kunci yang dapat dilakukan kepala sekolah agar dapat meningkatkan belajar dan pembelajaran, jelas bahwa kepala sekolah harus berperan sebagai leaders for learning. Para kepala sekolah harus mengetahui isi pelajaran dan teknik-teknik pedagogis. Para kepala sekolah harus bekerja bersama guru untuk meningkatkan keterampilan. Kepala sekolah harus mengumpulkan, menganalisis, dan menggunakan data dengan cara-cara yang menumbuhkan keunggulan. untuk meningkatkan kinerja siswa. Meskipun masyarakat pada umumnya memberi sorotan 
kepada kepala sekolah ketika hasil Ujian Nasional siswa diumumkan dan mengajukan usul untuk memberi sanksi apabila sekolah tidak menunjukkan hasil sebagaimana diharapkan, para kepala sekolah di masa lalu tidak banyak melalukan persiapan atau melakukan pengembangan keprofesionalan berkelanjutan untuk membekali diri dalam rangka melaksanakan peran baru tersebut.

\section{Kajian Instrumen Penilaian Hasil Belajar}

Instrumen merupakan suatu alat yang dipergunakan sebagai alat untuk mengukur suatu objek ukur atau mengumpulkan data dari suatu variabel. Kusaeri (2015: 25) menyatakan bahwa secara umum yang dimaksud dengan instrumen adalah suatu alat yang karena memenuhi persyaratan akademis maka dapat dipergunakan sebagai alat untuk mengukur suatu objek ukur atau mengumpulkan data mengenai suatu variabel. Selain itu, Haryati (2010: 45) juga menambahkan bahwa instrumen penilaian adalah alat yang digunakan untuk menilai capaian pembelajaran peserta didik, misalnya: tes dan skala sikap. Sedangkan Kusaeri (2015: 98) menyebutkan bahwa instrumen penilaian adalah suatu alat yang digunakan sebagai alat untuk mengukur, mengumpulkan, menganalisis, serta menginterpretasikan informasi untuk menentukan seberapa jauh seorang siswa atau sekelompok siswa mencapai tujuan pembelajaran yang telah ditetapkan, baik aspek pengetahuan, sikap maupun keterampilan.

Penilaian bukanlah sekumpulan teknik semata-mata, tetapi penilaian merupakan suatu proses yang berkelanjutan yang mendasari keseluruhan kegiatan pembelajaran yang baik. Penilaian pembelajaran bertujuan untuk mengetahui sampai sejauh mana efisiensi proses pembelajaran yang dilaksanakan dan efektifitas pencapaian tujuan pembelajaran yang telah ditetapkan. Dalam rangka kegiatan pembelajaran, evaluasi dapat didefinisikan sebagai suatu proses sistematik dalam menentukan tingkat pencapaian tujuan pembelajaran yang telah ditetapkan.

\section{Kajian In House Training (IHT)}

\section{a. Pengertian In House Training (IHT)}

In House Training merupakan pelatihan yang terjadi atas permintaan suatu komunitas tertentu apakah itu lembaga profit ataupun non-profit (Lulu, 2011). Istilah In House Training sama pengertiannya dengan In Service Training. Menurut Mawansyah (2010: 92) menyatakan bahwa In Service Training sebagai usaha untuk meningkatkan pengetahuan dan keterampilan guru dalam bidang tertentu sesuai dengan tugasnya agar dapat meningkatkan efisiensi dan produktivitas dalam bidang tersebut. Lebih lanjut dikemukakan bahwa program in-servis training ini diperlukan karena banyak guru-guru muda yang belum mendapat pengalaman dan bekal yang cukup dalam menghadapi pekerjaannya. Agar program In Service Training ini efektif memerlukan manajemen pelatihan seperti dikemukakan (Lulu, 2011) diantaranya adalah pengembangan mutu sumber daya manusia memerlukan manajemen yang secara logis perlu mengikuti tahapan penilaian, merumuskan tujuan dan sasaran, mengembangkan program, menyusun rencana kegiatan, melaksanakan program, monitoring dan supervisi serta evaluasi program. 
SEUNEUBOK LADA

Jurnal Ilmu-Ilmu Sejarah, Sosial, Budaya dan Kependidikan, 7 (1), 2020: 93-106

ISSN : 2356-0770

e-ISSN : 2685-2705

\section{b. Langkah-Langkah Pelaksanaan In House Training (IHT)}

Mawansyah (2012: 170) menyebutkan bahwa IHT dilakukan melalui tiga fase yaitu; 1) fase perencanaan, berfungsi untuk menentukan tujuan atau kerangka tindakan yang diperlukan untuk mencapai tujuan tertentu. Kegiatan ini meliputi; menentukan tujuan, menentukan materi, menentukan pendekatan dan metodologi pelatihan, menentukan peserta pelatihan dan fasilitator (trainer), menentukan waktu dan tempat, menentukan semua bahan, menentukan model evaluasi pelatihan, menentukan sumber dana dan pembiayaan yang dibutuhkan; 2) fase proses penyelenggaraan yang meliputi persiapan kelengkapan bahan pelatihan dan sarana prasarana; dan 3) fase evaluasi adalah fase penilaian terhadap kegiatan pelatihan yang telah dilaksanakan.

Dengan melakukan fase sebagaimana tersebut diatas, diharapkan sasaran dari program kegiatan menjadi lebih jelas. Fase atau langkah pengembangan dimaksudkan untuk merancang dan melaksanakan program dalam rangka mencapai sasaran kegiatan yang telah ditetapkan. Sedangkan evaluasi dimaksudkan untuk mengetahui sampai sejauhmana kegiatan yang dilaksanakan dapat mencapai sasaran yang telah ditetapkan.

\section{PEMBAHASAN}

Pelaksanaan penelitian mengacu pada rencana sembelumnya yakni dilakukan pada guru-guru SD Negeri Alue Gureb Kec. Peureulak Timur, Kab. Aceh Timur sebanyak 10 orang guru. Penelitian tindakan tersebut dilaksanakan dalam dua siklus. Pada masing-masing siklus dilakukan dua kali kegiatan In House Training (IHT) yang meliputi kegiatan perencanaan, pelaksanaan, dan penilaian. Berdasarkan hasil penelitian yang telah dilakukan bahwa implementasi In House Training (IHT) dapat meningkatkan kompetensi guru dalam menyusun instrumen penilaian hasil belajar di SD Negeri Alue Gureb, Kec. Peureulak Timur, Kab. Aceh Timur. Hal tersebut dapat dianalisis dan dibahas sebagai berikut:

\section{Pembahasan Hasil Kegiatan Kondisi Awal}

Sebelum dilaksanakan penelitian, gambaran kondisi awal terkait kompetensi para guru di SD Negeri Alue Gureb, Kec. Peureulak Timur, Kab. Aceh Timur dalam menyusun instrumen penilaian hasil belajar sangatlah rendah. Guru-guru masih kesulitan di dalam menyusun rancangan instrumen penilaian hasil belajar yang baik dan benar, terutama instrumen penilaian hasil belajar untuk semua kompetensi dasar yang mencakup sikap, pengetahuan, dan keterampilan. Pada prinsipnya, instrumen penilaian adalah suatu alat yang digunakan sebagai alat untuk mengukur, mengumpulkan, menganalisis, serta menginterpretasikan informasi untuk menentukan seberapa jauh seorang siswa atau sekelompok siswa mencapai tujuan pembelajaran yang telah ditetapkan, baik aspek pengetahuan, sikap maupun keterampilan. 
Hal ini tentu saja sangat berpengaruh pada efektifitas proses pembelajaran dan dapat menyebabkan mutu pendidikan menjadi rendah. Dari 10 orang guru hanya 2 orang $(20 \%)$ guru yang mampu merancang instrumen penilaian hasil belajar yang baik dan benar serta sudah menerapkannya. Sedangkan selebihnya sebanyak 8 orang guru $(80 \%)$ belum mampu merancang instrumen penilaian hasil belajar yang baik dan benar serta belum bisa menerapkan dalam proses pembelajaran. Selebihnya masih meng-copy paste rancangan instrumen penilaian hasil belajar sekolah lain dengan beberapa perubahan-perubahan.

Permasalahan tersebut tentu saja tidak dapat dibiarkan terus menerus, tetapi harus ada solusi atau tindakan nyata dari kalangan kepala sekolah dan pengawas. Berkaitan dengan itu, para guru harus dibina dan diberikan pelatihan untuk meningkatkan kemampuannya dalam menyusun instrumen penilaian hasil belajar.

\section{Pembahasan Hasil Kegiatan Siklus I}

Gambaran hasil tindakan pada pelaksanaan siklus I menunjukkan adanya sedikit peningkatan kompetensi guru dalam menyusun instrumen penilaian hasil belajar dibandingkan dengan kondisi awal walaupun belum mencapai hasil sesuai dengan yang diharapkan. Pada siklus I, secara garis besar penyusunan instrumen penilaian hasil belajar melalui implementasi In House Training (IHT) sudah dilaksanakan dengan baik, tetapi daya serap guru terhadap materi yang disampaikan narasumber belum semuanya terakumulasikan dengan baik, karena implementasi In House Training (IHT) tersebut masih dirasakan baru oleh guru.

Selama kegiatan In House Training (IHT) berlangsung, kegiatan peserta juga diobservasi mengenai kerjasama dalam tim, daya serap terhadap materi kegiatan, kemampuan IT, kualitas tugas yang dihasilkan, serta antusiasme peserta terhadap kegiatan. Berdasarkan data hasil penelitian, diketahui bahwa dari aspek kerjasama dalam tim 7 guru (70\%), daya serap terhadap materi kegiatan terdapat 7 guru (70\%), kemampuan IT hanya 5 orang guru (50\%), kualitas tugas yang dihasilkan hanya 8 orang guru (80\%), dan antusiasme peserta terhadap kegiatan In House Training (IHT) secara positif terdapat 8 orang guru $(80 \%)$. Secara umum hasil yang dicapai sudah meningkat namun masih jauh dari target yang diharapkan.

Dalam implementasi In House Training (IHT) pada siklus I ini masih terdapat kekurangan, sehingga perlu adanya revisi untuk dilakukan pada siklus berikutnya. Adapun hal-hal yang perlu diperhatikan dalam merevisi tindakan pada siklus berikutnya diantaranya adalah;

a. Sebagian besar guru peserta kegiatan In House Training (IHT) belum mampu mengoperasikan laptop/komputer, karena keterbatasan keterampilan dan pengetahuan. Padahal dengan adanya media laptop/komputer maka penyusunan instrumen penilaian hasil belajar akan lebih mudah dan teratur dalam hal penulisannya. Oleh karena itu, akan dilakukan pelatihan skill guru untuk menambah kemampuan dan pengetahuan menggunakan media laptop/komputer. 
b. Guru kesulitan dalam menyusun redaksi kalimat sehingga tidak sesuai dengan tingkat pencapaian siswa dengan tujuan pembelajaran. Oleh karena itu akan dilakukan pelatihan dalam penyesuaian kata dan perbanyak mengolah referensi bahasa.

c. Ada beberapa guru yang belum mampu merumuskan penilaian pada kompetensi penilaian sikap, pengetahuan dan keterampilan. Hal ini disebabkan kurangnya pengetahuan sang guru akan materi yang diajarkan dan kurangnya konsentrasi guru dalam mengajar yang bisa menyebabkan arah pembelajaran didalam kelas menjadi tidak teratur. Perlu diberikan pengarahan secara individu kepada guru peserta bagaimana cara merumuskan tujuan pembelajaran dengan baik agar proses pembelajaran berjalan lancar.

d. Masih banyak guru yang belum mengetahui langkah-langkah kegiatan penyusunan instrumen penilaian hasil belajar yang teratur dan sistematis. Untuk mengatasi masalah ini, akan diberikan arahan dan cara-cara penyusunan instrumen penilaian hasil belajar yang benar yang akan disampaikan oleh narasumber.

Berdasarkan hasil yang dicapai pada pelaksanaan tindakan siklus I tersebut, peneliti merasa belum puas atas pencapaian tersebut. Oleh karena itu peneliti melanjutkan pada siklus II dengan terlebih dahulu melakukan perbaikan atas kelemahan yang terjadi pada siklus sebelumnya.

\section{Pembahasan Hasil Kegiatan Siklus II}

Pada pelaksanaan tindakan siklus II terjadi peningkatan yang cukup signifikan dibandingkan dengan hasil tindakan siklus I. Hal ini disebakan peneliti secara terus menerus melakukan bimbingan dan arahan kepada para guru agar mampu meningkatkan kompetensinya dalam menyusun instrumen penilaian hasil belajar secara baik sehingga proses pembelajaran menjadi lebih efektif yang pada akhirnya akan meningkatkan mutu pendidikan.

Dalam tindakan siklus II selama kegiatan In House Training (IHT) berlangsung, kegiatan peserta juga diobservasi, mengenai kerjasama dalam tim, daya serap terhadap materi kegiatan, kemampuan IT, kualitas tugas yang dihasilkan, serta antusiasme peserta terhadap kegiatan. Berdasarkan data hasil penelitian, diketahui bahwa kesiapan guru SD Negeri Alue Gureb dalam mengikuti kegiatan In House Training (IHT) diperoleh data dari segi aspek kerjasama dalam tim 9 guru (90\%), daya serap terhadap materi kegiatan terdapat 10 guru (100\%), kemampuan IT hanya 6 orang guru (60\%), kualitas tugas yang dihasilkan sebanyak 9 orang guru (90\%), dan antusiasme peserta terhadap kegiatan In House Training (IHT) secara positif terdapat 10 orang guru $(100 \%)$.

Berdasarkan perolehan hasil analisis pada siklus ke II ini, didapat disimpulkan bahwa keberhasil guru dalam meningkatkan kompetensinya dalam menyusun instrumen penilaian hasil belajar melalui kegiatan In House Training (IHT) menunjukkan angka yang sangat memuaskan dan sesuai dengan apa yang 
SEUNEUBOK LADA

Jurnal Ilmu-Ilmu Sejarah, Sosial, Budaya dan Kependidikan, 7 (1), 2020: 93-106

ISSN : 2356-0770

e-ISSN : 2685-2705

diharapkan. Secara garis besar penelitian dianggap berhasil karena dari hasil refleksi yang didapat dari hasil observasi siklus II diketahui hal-hal sebagai berikut:

a. Kemampuan guru dalam memahami kompetensi penilaian pada aspek sikap, pengetahuan dan keterampilan. Hal ini karena dilakukannya pelatihan dan pembinaan tentang materi secara individu maupun kelompok.

b. Dalam hal memahami langkah-langkah penyusunan instrumen penilaian hasil belajar sudah teratur dan sistematis. Hal ini dikarenakan pembinaan dan pemantapan materi yang diberikan narasumber kepada guru, sangat detail dan terarah sehingga guru mudah mengerti bagaimana penyusunan yang benar.

c. Untuk mengembangkan dan mengorganisasikan materi serta pemecahan permasalahan juga mengalami peningkatan. Hasil ini dicapai karena adanya diskusi pemecahan masalah dari contoh instrumen penilaian hasil belajar yang disajikan, pengenalan solusi dan pembaruan metode membuat guru peserta menjadi terlatih serta penambahan pengetahuan.

Kompetensi guru yang telah mengalami peningkatan karena diadakannya kegiatan In House Training (IHT) ini, perlu dilakukan pembinaan berkelanjutan dan melakukan supervisi kepada guru baik dari pihak kepala sekolah maupun pihak pengawas sekolah secara optimal sehingga para guru tetap konsisten melakukan rancangan dalam instrumen penilaian hasil belajar. Hal ini juga sangat bermanfaat bagi kualitas guru dan meningkatkan kesuksesan proses belajar mengajar di SD Negeri Alue Gureb, Kec. Peureulak Timur, Kab. Aceh Timur.

Dengan demikian peneliti menetapkan bahwa Penelitian Tindakan Sekolah ini dirasa telah memadai hanya pada siklus II dan tidak melanjutkan ke siklus berikutnya karena nilai rata-rata telah mencapai indikator keberhasilan penelitian sebagaimana yang diharapkan.

Agar lebih jelas gambaran peningkatan kemampuan guru dalam menyusun instrumen penilaian hasil belajar dari kondisi awal, siklus I dan siklus II, dapat dilihat dan diperhatikan pada rekapitulasi tabel dan grafik berikut:

Tabel 1. Rekapitulasi perbandingan Kompetensi Guru dalam Menyusun Instrumen Penilaian Hasil Belajar setiap siklus

\begin{tabular}{|c|l|c|c|c|c|c|c|}
\hline \multirow{2}{*}{ No } & \multicolumn{1}{|c|}{ Keterangan } & \multicolumn{2}{|c|}{ Kondisi Awal } & \multicolumn{2}{c|}{ Siklus I } & \multicolumn{2}{c|}{ Siklus II } \\
\cline { 2 - 7 } & $\begin{array}{c}\text { Jumlah } \\
\text { Guru }\end{array}$ & Persentase & $\begin{array}{c}\text { Jumlah } \\
\text { Guru }\end{array}$ & Persentase & $\begin{array}{c}\text { Jumlah } \\
\text { Guru }\end{array}$ & Persentase \\
\hline 1. & $\begin{array}{l}\text { Mampu Menyusun } \\
\text { Instrumen Penilaian } \\
\text { Hasil Belajar }\end{array}$ & 2 & $20 \%$ & 5 & $50 \%$ & 9 & $90 \%$ \\
\hline 2. & $\begin{array}{l}\text { Belum Mampu } \\
\text { Menyusun Instrumen } \\
\text { Penilaian Hasil Belajar }\end{array}$ & 8 & $80 \%$ & 5 & $50 \%$ & 1 & $10 \%$ \\
\hline \multicolumn{1}{|l}{ Jumlah } & 10 & $100 \%$ & 10 & $100 \%$ & 10 & $100 \%$ \\
\hline
\end{tabular}

Berdasarkan data tabel di atas dapat digambarkan pada grafik diagram batang di bawah ini: 


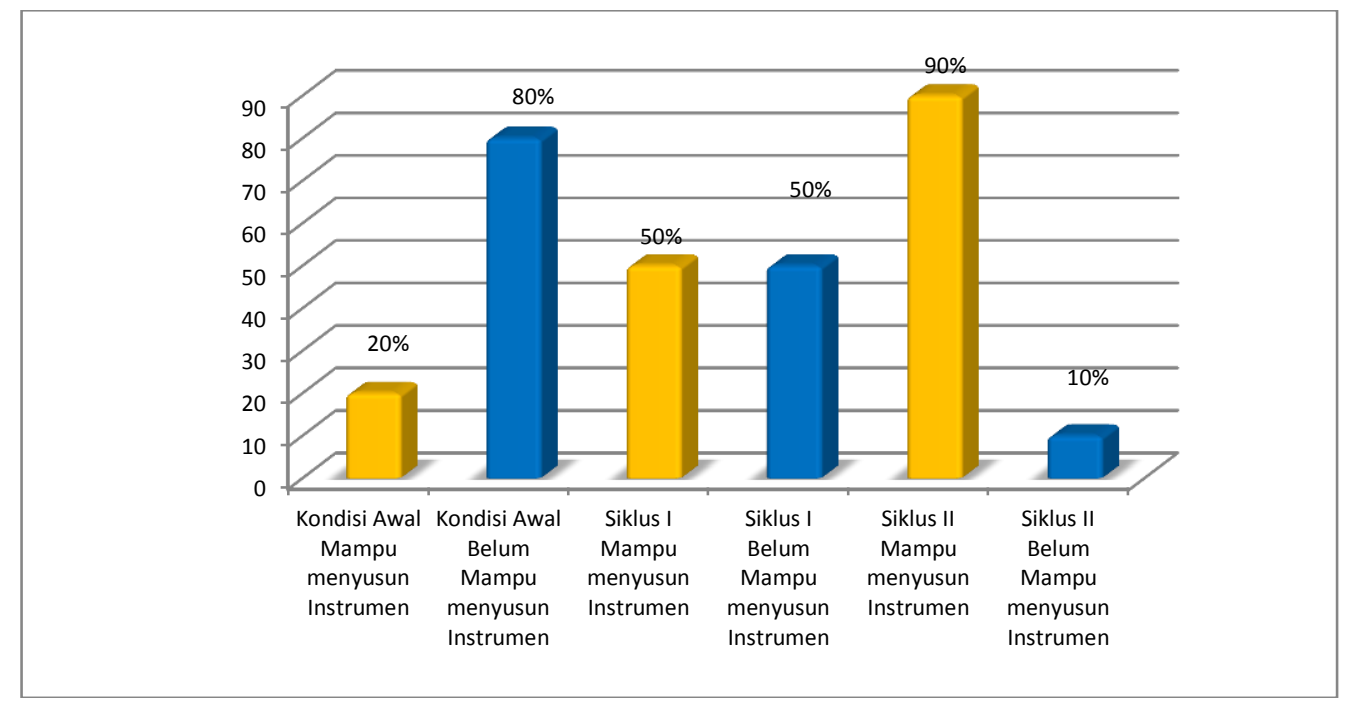

Gambar 1.1 Grafik Perbandingan Kompetensi Guru dalam Menyusun Instrumen Penilaian Hasil Belajar Setiap Siklus

Dalam kegiatan In House Training (IHT) berlangsung, kegiatan peserta juga diobservasi, mengenai kerjasama dalam tim, daya serap terhadap materi kegiatan, kemampuan IT, kualitas tugas yang dihasilkan, serta antusiasme peserta terhadap kegiatan. Adapun hasil observasi sebagai berikut;

Tabel 1.2 Rekapitulasi Perbandingan Kesiapan Guru dalam Mengikuti In House Training (IHT) Siklus I dan II

\begin{tabular}{|c|c|c|c|c|c|c|c|c|c|c|c|}
\hline \multirow{2}{*}{ No } & \multirow{2}{*}{$\begin{array}{c}\text { Aspek yang } \\
\text { diamati }\end{array}$} & \multicolumn{4}{|c|}{ Siklus I } & \multirow{2}{*}{ Kriteria } & \multicolumn{4}{|c|}{ Siklus II } & \multirow{2}{*}{ Kriteria } \\
\hline & & $\mathrm{T}$ & Persentase & $\mathrm{R}$ & Persentase & & $\mathrm{T}$ & Persentase & $\mathrm{R}$ & Persentase & \\
\hline 2 & Daya Serap & 7 & $70 \%$ & 3 & $30 \%$ & Cukup & 10 & $100 \%$ & - & $0 \%$ & $\begin{array}{l}\text { Amat } \\
\text { Baik }\end{array}$ \\
\hline 5 & Antusiasme & 8 & $80 \%$ & 2 & $20 \%$ & Baik & 10 & $100 \%$ & - & $0 \%$ & $\begin{array}{l}\text { Amat } \\
\text { Baik }\end{array}$ \\
\hline
\end{tabular}

Keterangan:

$\mathrm{T}=$ Tinggi

$\mathrm{R}=$ Rendah

Rentang Skor

$86 \%-100 \%=$ Amat Baik $(\mathrm{A})$

$71 \%-85 \%=$ Baik (B)

$56 \%-70 \%=$ Cukup $(\mathrm{C})$

$41 \%-55 \%=$ Kurang (D)

$01 \%-40 \%=$ Buruk (E) 
SEUNEUBOK LADA

Jurnal Ilmu-Ilmu Sejarah, Sosial, Budaya dan Kependidikan, 7 (1), 2020: 93-106

ISSN : 2356-0770

e-ISSN : 2685-2705

Data pada tabel di atas jika di gambarkan dalam grafik maka akan tampak seperti berikut;

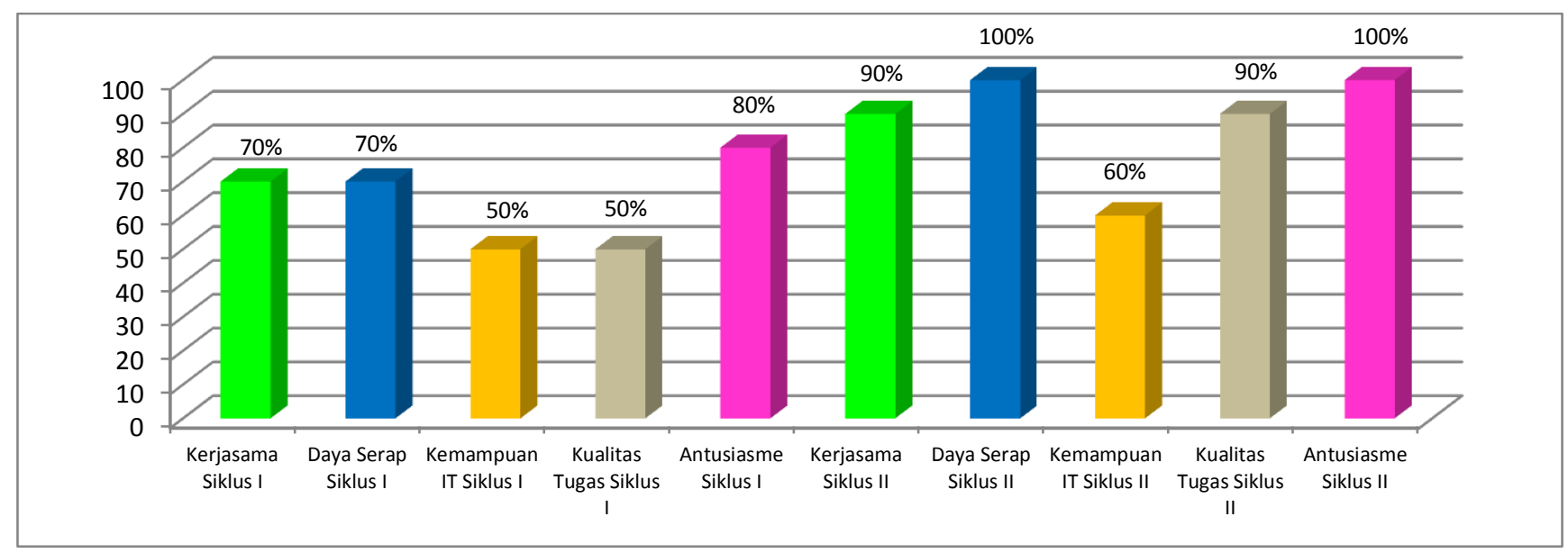

Gambar 1.2 Grafik Perbandingan Kesiapan Guru dalam Mengikuti In House Training (IHT) Siklus I dan II

Dari paparan data melalui tabel dan grafik, diketahui bahwa pada kondisi awal, dari 10 orang guru hanya 2 orang (20\%) guru yang mampu merancang instrumen penilaian hasil belajar yang baik dan benar serta sudah menerapkannya. Sedangkan selebihnya sebanyak 8 orang guru $(80 \%)$ belum mampu merancang instrumen penilaian hasil belajar yang baik dan benar serta belum bisa menerapkan dalam proses pembelajaran. Sedangkan setelah dilaksanakan penelitian terutama pada siklus I, maka terlihat peningkatan, dimana dari 10 orang guru, sejumlah 5 orang (50\%) guru yang mampu membuat instrumen penilaian hasil belajar dan sudah menerapkannya. Sedangkan selebihnya sebanyak 5 orang guru (50\%) belum mampu menyusun instrumen penilaian hasil belajar yang baik dan benar serta belum bisa menerapkan dalam proses pembelajaran.

Demikian pula mengenai kesiapan guru SD Negeri Alue Gureb dalam mengikuti kegiatan In House Training (IHT) siklus I, diperoleh data dari segi aspek kerjasama dalam tim 7 guru (70\%), daya serap terhadap materi kegiatan terdapat 7 guru (70\%), kemampuan IT hanya 5 orang guru (50\%), kualitas tugas yang dihasilkan hanya 5 orang guru $(50 \%)$, dan antusiasme peserta terhadap kegiatan In House Training (IHT) secara positif terdapat 8 orang guru (80\%). Secara umum hasil yang dicapai sudah meningkat namun masih jauh dari target yang diharapkan. Secara umum hasil yang dicapai sudah meningkat namun masih jauh dari target yang diharapkan.

Selanjutnya pada siklus II, dari 10 orang guru, sejumlah 9 orang guru (90\%) guru yang mampu membuat instrumen penilaian hasil belajar dan sudah menerapkannya. Sedangkan selebihnya sebanyak 1 orang guru (10\%) belum mampu menyusun instrumen penilaian hasil belajar yang baik dan benar serta belum bisa menerapkan dalam proses pembelajaran. 
Demikian pula mengenai kesiapan guru SD Negeri Alue Gureb dalam mengikuti kegiatan In House Training (IHT) siklus II, diperoleh data dari segi aspek kerjasama dalam tim 9 guru (90\%), daya serap terhadap materi kegiatan terdapat 10 guru (100\%), kemampuan IT hanya 6 orang guru (60\%), kualitas tugas yang dihasilkan hanya 9 orang guru (90\%), dan antusiasme peserta terhadap kegiatan In House Training (IHT) secara positif terdapat 10 orang guru (100\%).

Dengan demikian peneliti menetapkan bahwa Penelitian Tindakan Sekolah ini dirasa telah memadai hanya pada siklus II dan tidak melanjutkan ke siklus berikutnya karena nilai rata-rata telah mencapai indikator keberhasilan penelitian sebagaimana yang diharapkan.

\section{KESIMPULAN}

Berdasarkan hasil penelitian dan tujuan yang diharapkan dalam penelitian ini, maka ditarik kesimpulan sebagai berikut.

1. Kegiatan In House Training (IHT) peningkatan kompetensi guru dalam menyusun rancangan instrumen penilaian hasil belajar di SD Negeri Alue Gureb memberikan hasil yang bermanfaat bagi guru. Hal ini ditunjukkan dengan meningkatnya pemahaman guru terhadap rancangan instrumen penilaian hasil belajar sehingga dapat berpengaruh positif terhadap kualitas pembelajaran di SD Negeri Alue Gureb.

2. Kemampuan guru dalam merancang instrumen penilaian hasil belajar meningkat setiap siklus. pada kondisi awal, dari 10 orang guru hanya 2 orang (20\%) guru yang mampu merancang instrumen penilaian hasil belajar yang baik dan benar serta sudah menerapkannya. Sedangkan selebihnya sebanyak 8 orang guru (80\%) belum mampu merancang instrumen penilaian hasil belajar yang baik dan benar serta belum bisa menerapkan dalam proses pembelajaran. Sedangkan setelah dilaksanakan penelitian terutama pada siklus I, maka terlihat peningkatan, dimana dari 10 orang guru, sejumlah 5 orang (50\%) guru yang mampu membuat instrumen penilaian hasil belajar dan sudah menerapkannya. Sedangkan selebihnya sebanyak 5 orang guru (50\%) belum mampu menyusun instrumen penilaian hasil belajar yang baik dan benar serta belum bisa menerapkan dalam proses pembelajaran. Berikutnya pada siklus II, dari 10 orang guru, sejumlah 9 orang (90\%) guru yang mampu membuat instrumen penilaian hasil belajar dan sudah menerapkannya. Sedangkan selebihnya sebanyak 1 orang guru (10\%) belum mampu menyusun instrumen penilaian hasil belajar yang baik dan benar serta belum bisa menerapkan dalam proses pembelajaran.

3. Sedangkan kesiapan guru SD Negeri Alue Gureb dalam mengikuti kegiatan In House Training (IHT) siklus I, diperoleh data dari segi aspek kerjasama dalam tim 7 guru (70\%), daya serap terhadap materi kegiatan terdapat 7 guru (70\%), kemampuan IT hanya 5 orang guru (50\%), kualitas tugas yang dihasilkan hanya 5 orang guru $(50 \%)$, dan antusiasme peserta terhadap kegiatan In House Training (IHT) secara positif terdapat 8 orang guru (80\%). Secara umum hasil yang dicapai sudah meningkat namun masih jauh dari target yang diharapkan. Secara umum hasil yang dicapai sudah meningkat namun masih jauh dari target 
yang diharapkan. Pada siklus II, diperoleh data dari segi aspek kerjasama dalam tim 9 guru (90\%), daya serap terhadap materi kegiatan terdapat 10 guru (100\%), kemampuan IT hanya 6 orang guru $(60 \%)$, kualitas tugas yang dihasilkan hanya 9 orang guru (90\%), dan antusiasme peserta terhadap kegiatan In House Training (IHT) secara positif terdapat 10 orang guru (100\%).

\section{DAFTAR PUSTAKA}

Hadi, S. (2009) Kepemimpinan Pembelajaran. Jakarta: Departemen Pendidikan Nasional, Direktorat Jenderal Peningkatan Mutu Pendidik dan Tenaga Kependidikan, Direktorat Tenaga Kependidikan.

Hamalik, O. 2008. Pendidikan Guru Berdasarkan Pendekatan Kompetensi. Jakarta: Bumi Aksara.

Haryati, M. 2010. Model dan Teknik Penilaian pada Tingkat Satuan Pendidikan. Jakarta: Gaung Persada Press Jakarta.

Kusaeri. 2015. Acuan dan Teknik Penilaian Proses serta Hasil Belajar dalam Kurikulum 2013. Yogyakarta: Ar-Ruzz Media.

Lulu, K. 2011. Pengertian In House Training, Tujuan dan Manfaatnya. http:// tikettraining.com/ pengertian-in-house-training-tujuan-dan manfaatnya.

Mawansyah. 2010. Manajemen Sumber Daya Manusia. Bandung: Alfabeta.

Pidarta, M. 2011. Pemikiran Tentang Supervisi Pendidikan. Jakarta: Bumi Aksara.

Sagala, S. 2009. Kemampuan Profesional Guru dan Tenaga Kependidikan. Bandung: Alfabeta.

Syaeffudin, U. 2010. Pengembangan Profesi Guru. Bandung: Alfabeta. 